\title{
Sex-ratio, seasonality and long-term variation in maturation and spawning of the brown shrimp Crangon crangon (L.) in the German Bight (North Sea)
}

\author{
V. Siegel · U. Damm · T. Neudecker
}

Received: 4 August 2007/Revised: 11 June 2008/Accepted: 17 June 2008/Published online: 10 July 2008

(C) Springer-Verlag and AWI 2008

\begin{abstract}
Aspects of the reproductive and maturation biology of the brown shrimp Crangon crangon (L.) were studied in various subareas of the German Bight (North Sea). The size-specific sex ratio of $C$. crangon was examined based on length frequency distribution data. The sex ratio for the smallest size groups at which sex was determined was typically around 0.5 , indicating an even ratio between males and females. The proportion of females decreased in the $30-45 \mathrm{~mm}$ size range. In length classes larger than $50 \mathrm{~mm}$, the proportion of females constantly increases to $100 \%$ at around $60 \mathrm{~mm}$ total length. We concluded that sex reversal from male to female may not occur in $C$. crangon. Size at sexual maturity was determined from the proportion of ovigerous females. Size at maturity $\left(L_{50}\right)$ was estimated as 55.4 and $62.0 \mathrm{~mm}$ total length for spring and winter data, respectively. The seasonal spawning cycle was studied over the period 1958-2005. Between mid February and late June and for size classes larger than $65 \mathrm{~mm}$ ovigerous shrimps exceeded $80 \%$ and reached up to $100 \%$ of the females in the population. This period can be seen as the core spawning season. From early August to early December the proportion of ovigerous shrimps in the female population is very low. Interannual differences in the seasonal process are obvious with a dramatic decline in C. crangon reproductive success in the late 1980s. Various options are discussed for the reasons of the decline and recovery of the reproductive performance.
\end{abstract}

Communicated by F. Buchholz.

V. Siegel $(\varangle) \cdot$ U. Damm · T. Neudecker Institut für Seefischerei, Palmaille 9, 22767 Hamburg, Germany e-mail: volker.siegel@vti.bund.de

\section{Introduction}

The brown shrimp Crangon crangon is a key species in the German North Sea inshore waters and the Wadden Sea. It is an important prey species for many fish species, some of which are of great commercial importance, e.g. whiting and cod (Tiews 1970, 1978). It is also a significant predator, feeding on a variety of taxa of appropriate size (Plagmann 1939; Reise 1977, 1979; Pihl and Rosenberg 1984; Oh et al. 2001). At the same time brown shrimp are the target of a high-value commercial trawl fishery in the German Bight with annual landings over 15,000 tonnes by German and another 20,000 tonnes by Dutch and Danish fishing vessels inside or adjacent to the study region. A decline in $C$. crangon stock size or even a high variability in its abundance and biomass has immediate effects on the coastal marine food web as well as on the commercial exploitation.

Earlier studies have described seasonal patterns of occurrence of ovigerous females (e.g. Havinga 1930; Neudecker and Damm 1992) and the occurrence of differently sized winter and summer eggs (e.g. Havinga 1930; Boddeke 1982). However, the degree of interannual variation in maturation has not yet been considered in detail. Uncertainty also exists with regard to the relative importance of the two egg production seasons for the mass invasion of juvenile recruits typically in the range of 10$20 \mathrm{~mm}$ length in May-June, which is the characteristic seasonal signal in the German Wadden Sea. These recruits are presumed to grow into the exploitable stock by the autumn (Temming and Damm 2002). A comprehensive understanding of the sex ratio and the fraction of ovigerous females by size and season is necessary for an improved parameterization of the maturation and spawning processes in an individual-based life cycle model (Temming and 
Damm 2002), which at the present state considers only females and shall eventually cover yield/recruit simulations. Due to the pronounced seasonality of all relevant events in the life cycle of $C$. crangon such a model should represent a complex individual based forward simulation which mimics the seasonal development of the population and the fishery (Temming and Damm 2002). For this, a quantitative understanding of the $C$. crangon life cycle is essential to estimate the reactions of the population and the yields to different effort scenarios of the fishery.

\section{Materials and methods}

Three different data sources were used for the present study, the spring and autumn survey data of the international "Demersal Young Fish Survey, DYFS" which date back to 1974, the national "Winter Shrimp Survey" in January, and a series of by-catch samples from the commercial shrimp fishery, which covered the period 19581994 (e.g. Tiews 1990).

The study area covers the North and East Frisia Wadden Sea mostly inside the island chain and the outer estuary of the River Elbe. Sampling coverage and number of stations were not homogeneous throughout the years and areas, but dependant on number of working days and weather conditions. The area includes sandy bottom and deep channel systems as deep as $20 \mathrm{~m}$. The survey area is characterized by daily changing flood and ebb tides and high dynamics in salinity, light, oxygen, tidal as well as seasonal fluctuations in seawater temperature. The Wadden Sea is an open system and water quality, sediment and marine habitats are, to an important degree, influenced by the adjacent North Sea and the water runoff of the main rivers.

Since 1974, the German DYFS was carried out in routine twice a year in the Wadden Sea areas of Northern and Eastern Frisia and the Elbe estuary as part of an internationally coordinated survey (van Beek et al. 1989). Commercial shrimping vessels were chartered in AprilMay and September-October. An experimental 3-m beamtrawl with a mesh opening of $20 \mathrm{~mm}$ (stretched mesh) was used as the standard fishing gear. The number of sampled stations increased over the years from a minimum of about 100 stations in early years up to approximately 160 stations per season. The 15-min tows were carried out with the prevailing tidal current at a towing speed of approximately three knots (Neudecker et al. 1998). Fishing depth usually ranged from 2 to $15 \mathrm{~m}$. Data on area swept were recorded for each station. The entire samples were sorted to the species level and total numbers of specimens were counted and weighed. A sub-sample of at least 200 C. crangon is measured routinely. Between 1974 and 1996 only three size classes were recorded $(\leq 54,55-67,>67 \mathrm{~mm})$ for samples of $300 \mathrm{ml}$ of brown shrimp. From 1997 onwards total length measurements were carried out on samples of 200 animals (approximately $200 \mathrm{~g}$ ) with accuracy to the $\mathrm{mm}$ below. Ovigerous females were always identified and measured, for the three-size class measurements as well as during the study period when length measurements were done to the mm below. Since 2001 an increasing number of samples was sorted and measured by sex and maturity stage.

The winter shrimp survey was established in 1991 to estimate the effects of the expanding commercial winter fishery on the shrimp stock. The survey was conducted annually in January on board RV "Solea" and covered the area of the German Bight beyond the $10 \mathrm{~m}$ depth contour. The standard fishing gear was a commercial-sized 7-m beam trawl, and trawling time was $30 \mathrm{~min}$. The mesh size of the 7 and 3-m-beam trawl of the DYFS was identical, i.e. $20 \mathrm{~mm}$ stretched mesh. Since 2004 supplementary sampling took place by a chartered commercial fishing vessel using DYFS standard gear and methods also to cover a selected sampling site in the shallow waters of the Wadden Sea. Since 2001 measurements to the millimeter below and sex identification of shrimps were also introduced in the standard sampling protocols of the winter cruises.

For the sex ratio analysis only data from 2001 to 2005 DYFS and winter cruises were included, because for these years total length was measured to the millimeter below. Total length is the distance between the front of the scaphocerite and the tip of the telson. Shrimp were classified as juveniles, males, females without eggs and ovigerous females. Males and females were separated according to their secondary sexual characteristics, which is the difference in length and shape of the endopods of the first pair of pleopods and the presence or absence of an appendix masculine on the endopodits of the second pleopods (Ehrenbaum 1890; Tiews 1970). The separation of length frequency distributions for male and female shrimp allowed us to calculate sex ratios for each millimeter length class. For estimating length at sexual maturity of female shrimps the proportion of ovigerous females versus total length (TL) was fitted by a logistic equation, here written as

$p=\frac{1}{1+\mathrm{e}^{-k\left(\mathrm{TL}-L_{50}\right)}}$

where $p=$ estimated proportion of shrimps in ovigerous stage, $\mathrm{TL}=$ total length in $\mathrm{mm}, k=$ coefficient. Length at first maturity $L_{50}$ is defined as the length at which $50 \%$ of the female shrimp stock has attained sexual maturity and participated in the spawning event, i.e. the inflection point of the sigmoid curve. The fitting was done through maximum likelihood estimation, using SAS procedure 
GENMOD. Other calculations were carried out using the STATISTICA software package.

For the study of the seasonal development of ovigerous females we used data from by-catch samples from the commercial shrimp fishery across the entire year. Fecundity at size data as well as length frequency distributions based on millimeter size classes to calculate egg production standardized to area would have been the optimum to describe the seasonal and interannual variability in spawning success. However, these calculations were not possible for our historic data before 1997, because length measurements were done by $5 \mathrm{~mm}$ size bins. Therefore, we used the share of ovigerous females within each of the size classes as a proxy for maturity. During 1958-1994 samples from this fishery were taken from more than 5,000 commercial hauls in North Frisia and 3,225 hauls in East Frisia. Sampling was undertaken routinely with a density of up to 5-6 samples per week and landing site. Random samples of 101 of unsorted catch were taken by the fishermen and worked up at the site by trained operatives, or were deepfrozen and shipped to our laboratories in Hamburg. The entire samples were sorted to the species level and total numbers of specimens were counted. A sub-sample of at least 200 brown shrimp was measured as total length to the $0.5 \mathrm{~cm}$ below. Sex was not identified in organisms from the commercial samples, but ovigerous females were measured and recorded separately for each size group.

For the analysis of the interannual variability in the occurrence of ovigerous females in different sub-areas data were obtained from the commercial by-catch series from 1958 to 1992 and from the DYFS survey samples over 1994-2005. Millimetre measurements were combined to $5 \mathrm{~mm}$ bins to harmonize the input values with the measurements from the commercial catches. From these samples shrimp were not sorted into developmental stages, but specimens were only separated into ovigerous females and unidentified specimens. The fraction of ovigerous females was calculated for size classes larger than $50 \mathrm{~mm}$ only, because this reduced the risk to include males in the smaller size classes and falsely classify them as females in the calculation of the maturity ratio (see also "Results" on sex ratio).

\section{Results}

Sex ratio

The size-specific sex ratio of $C$. crangon was calculated from the length frequency distribution data from all major cruises in the different seasons from 2001 to 2005, i.e. 37 cruises in total. The proportion of females (sex ratio) was highly variable in the smaller size classes $(25-30 \mathrm{~mm})$
(Fig. 1), probably because of the relatively low number of specimens within these length classes. The initial proportion centered around 0.5 , indicating an even ratio between males and females at the size where external sexual characteristics are visible (about $25 \mathrm{~mm}$ ).

The proportion of females decreases within the 30 $45 \mathrm{~mm}$ size range. In the length classes larger than $50 \mathrm{~mm}$ the proportion of females constantly increases to $100 \%$ at around $60 \mathrm{~mm}$ total length. This pattern was observed in each year as well as in the different seasons when we carried out our surveys (Fig. 1). No decline in the proportion of females for the medium-size class range was found in winter, with a roughly $50 \%$ proportion over the critical size range. Lows and highs in the sex ratio across certain length classes are often observed when differences occur in the length frequency distribution between males and females. Length frequency distributions of males and females are given as an example from the spring surveys 2001-2004 (Fig. 2a-c). Males were more frequent in lowsize classes, sometimes outnumbering females. As a result, the size distribution pattern of males appeared more compressed in the graph than that of females.

\section{Length at first maturity}

The share of ovigerous females within each of the size classes from 25 to $80 \mathrm{~mm}$ was used as a proxy for maturity. Since our "maturity" classification is based only on the presence of attached eggs, it should rather be termed "apparent maturity". Figure 3 reflects the mean spring and winter situation for the years 2001-2005 in the entire German Bight. In winter 55-60 mm-size bin is the first to show substantial numbers of ovigerous females. First ovigerous females appeared in the 50 -mm-class. In spring

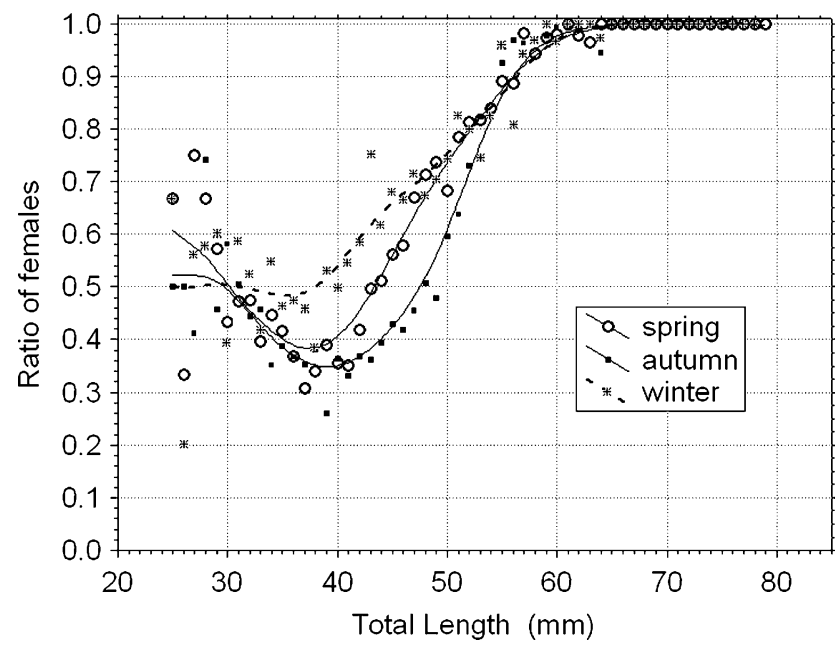

Fig. 1 Mean sex ratio of female shrimp in spring (2001-2004), autumn (2001-2005) and winter (2002-2005). Fitting of a trend line to data points was done by the distance weighted least square method 

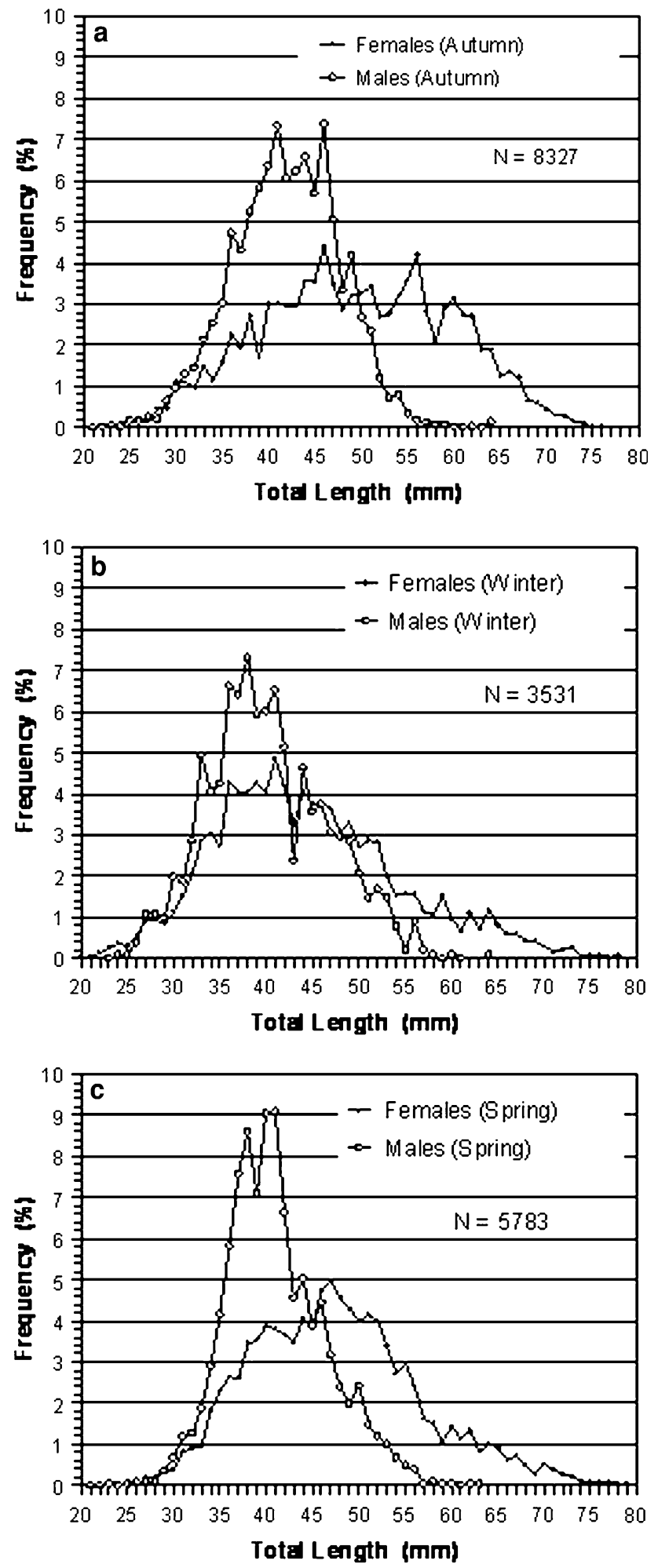

Fig. 2 Length frequency distributions by sexes of Crangon crangon from the spring DYF Surveys and the Winter Shrimp Survey 20012004, separated by seasons (a) September, (b) January, (c) April

the proportion of ovigerous females showed a shift to smaller size classes. This can best be seen from the results on length-at-maturity $L_{50}$, which decreased from $62.0 \mathrm{~mm}$ in winter to $55.4 \mathrm{~mm}$ in spring. Almost all the shrimps larger than $70 \mathrm{~mm}$ carried eggs. Results from the autumn surveys solely demonstrated that hardly any egg-bearing females occurred in the population during that time of the year.

Seasonal spawning cycle

Figure 4 displays the average seasonal proportion of ovigerous females by size class in pooled data from the commercial by-catch sampling over the period 1958-1992. Size classes smaller than $60 \mathrm{~mm}$ generally did not exceed a proportion of $50 \%$ of ovigerous females during the entire year. Size classes larger than $65 \mathrm{~mm}$ exceeded $80 \%$ between day 45 (mid February) and 170 (late June). This period can be seen as the core spawning season. From day 220 onwards (early August) the proportion of ovigerous females drops below $50 \%$ for all size classes. The absolute minimum with almost no ovigerous females is represented by steep troughs in all plots in Fig. $4 \mathrm{a}-\mathrm{d}$ and lasts until early December. A comparison between averaged longterm data from East and North Frisia (Fig. 4a, b) did not reveal any regional difference. The size-dependent proportion of ovigerous females was similar between the two areas as well as the timely development of ovigerous females in the course of the year.

Interannual variability

It has to be kept in mind that this very general pattern is based on data averaged over 35 years (1958-1992). However, the picture can vary between years and areas. A good example is available from the data set of East Frisia (Fig. 4c, d). For both periods, the proportion of ovigerous

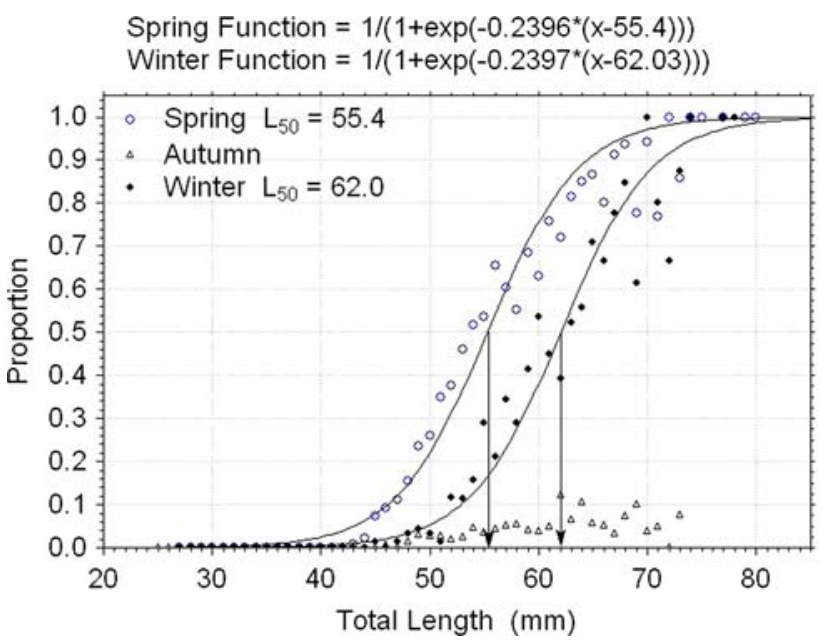

Fig. 3 Length at maturity of female shrimp from spring 2001-2004, autumn 2001-2005, and winter 2002-2005 survey data, arrows indicate the two locations of the two different $L_{50}$ values 
Fig. 4 Smoothed seasonal pattern of fraction of ovigerous female shrimp by length class from (a) North Frisia samples 1958-1992, (b) East Frisia 1958-1992, (c) East Frisia 1966-1976 and (d) East Frisia 1982-1991 a

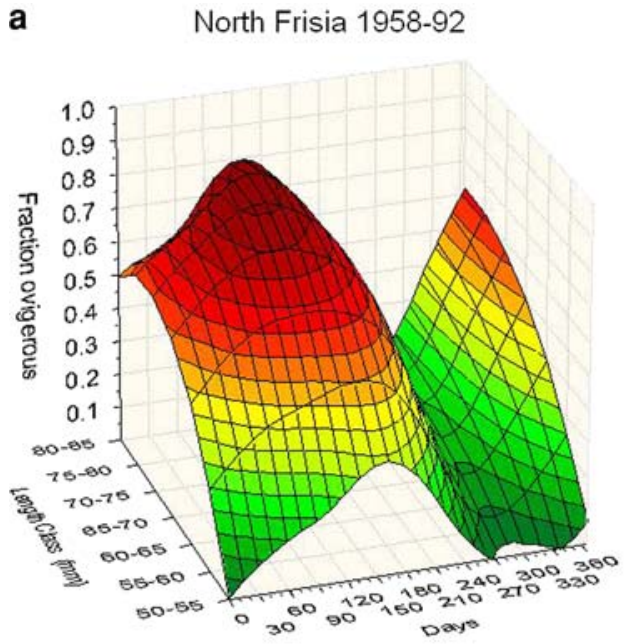

c

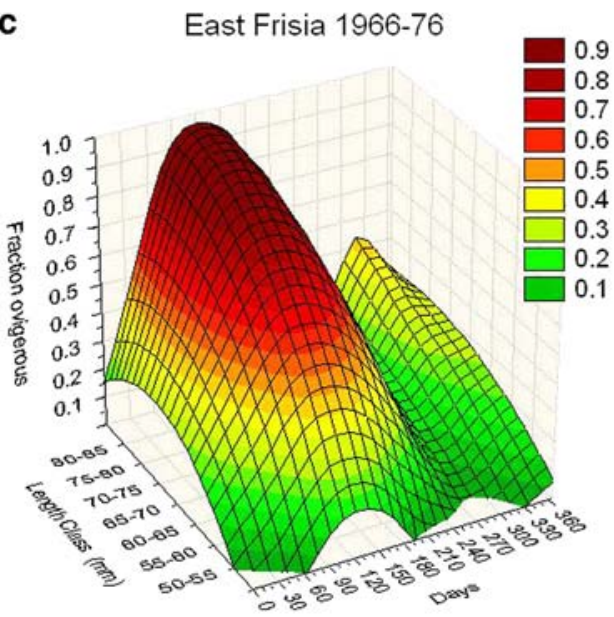

b East Frisia 1958-92

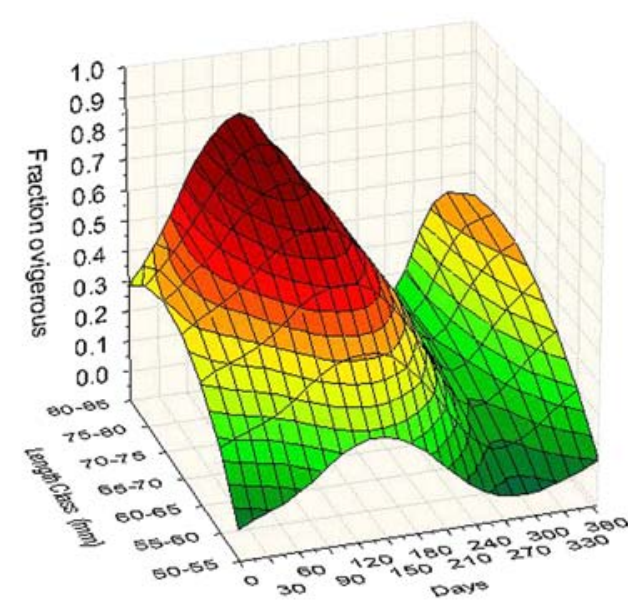

d

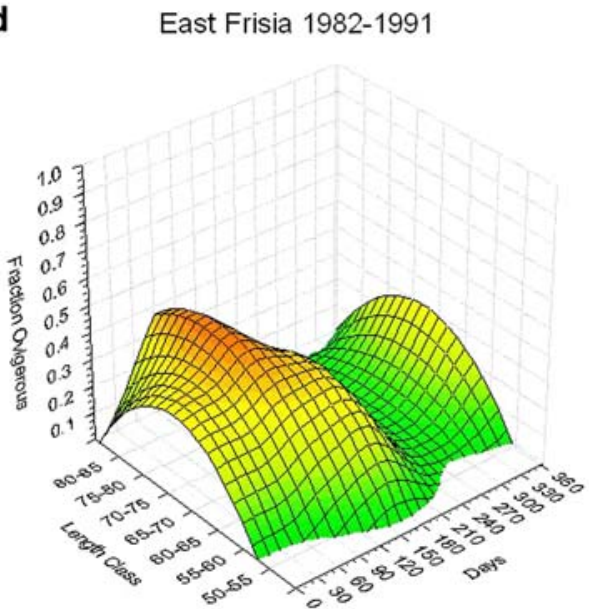

females showed the typical spring/early summer maximum, but higher in the earlier phase (1966-1976) where $100 \%$ for larger size classes are reached. On the other hand, from 1982 to 1991 the values were well below the average and the maximum proportion of ovigerous females hardly reached $40 \%$. These low values for ovigerous females occurred in all size classes.

During the early phase of the time series the fraction of ovigerous females larger than $50 \mathrm{~mm}$ varied roughly between 60 and $80 \%$. However, the time sequence of the data (Fig. 5) also revealed a trough of conspicuously low values in the 1980s. The downward trend was different for the various regions. The decrease in proportion of ovigerous females started first in the western part of the German Bight (East Frisia), probably around 1977 when it constantly dropped below 50\%. The absolute minimum occurred between 1988 and 1991 with proportions below $10 \%$. The recovery phase back to high proportions took only about 2 years. In the Elbe Estuary the decline started a little later than in East Frisia and was far less pronounced. In North Frisia the drop in proportion of ovigerous females did not occur before 1986 and was back to normal by 1990 , with one exception in 1992 when the proportion again fell below $10 \%$.

It was shown above that the proportion of ovigerous females is size-dependent. Since we included the size class $50-55 \mathrm{~mm}$ in the calculation of the proportion (which may not be fully mature), interannual differences in the occurrence of size groups might have led to the observed drop in egg-bearing females during the 1980s. We therefore calculated the relative proportion of very large $(>67 \mathrm{~mm})$ females over the years. We also analyzed the survey estimates of density of this group to look for interannual changes in the occurrence of mature egg-bearing females. Since East Frisia showed the strongest decline in proportions, the relative occurrence of large females is given for the same area in Fig. 6. Figure 7 shows the absolute density of large females $(>54 \mathrm{~mm})$ in all of the studied regions. Variability in proportions of ovigerous females was high between years. There was a weak indication for East Frisia that the proportion of large females was reduced in the stock after 1986. However, no significant trend could 

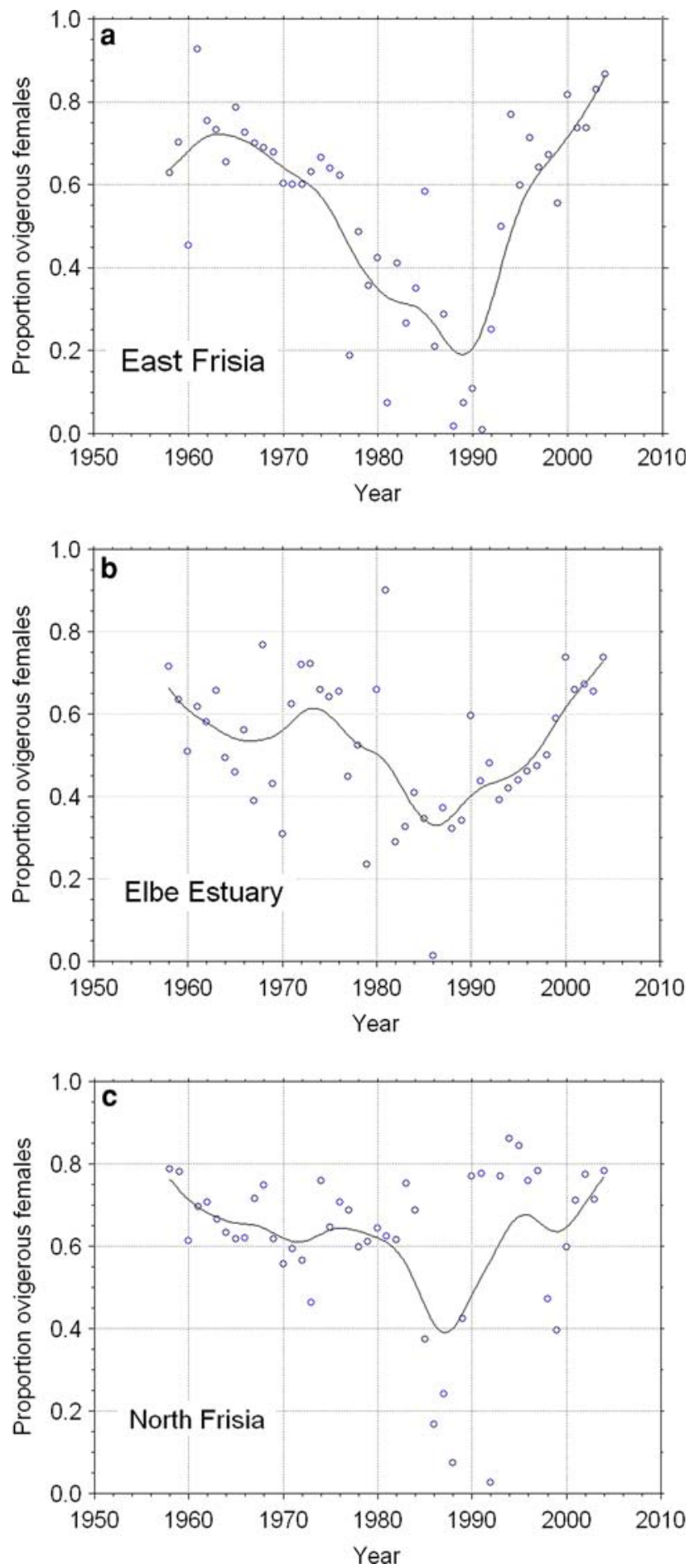

Fig. 5 Long-term interannual variation of fraction of ovigerous female shrimp (>54 mm) in spring (May) from 1958 to 2004. Data are derived from commercial by-catch sampling and scientific DYF Surveys, (a) East Frisia, (b) Elbe Estuary, (c) North Frisia. Fitting of the trend line to data points was done by the distance weighted least square method

be calculated and no similar indication was found for any of the other areas investigated. There was no general areawide decline in overall ovigerous females that could be

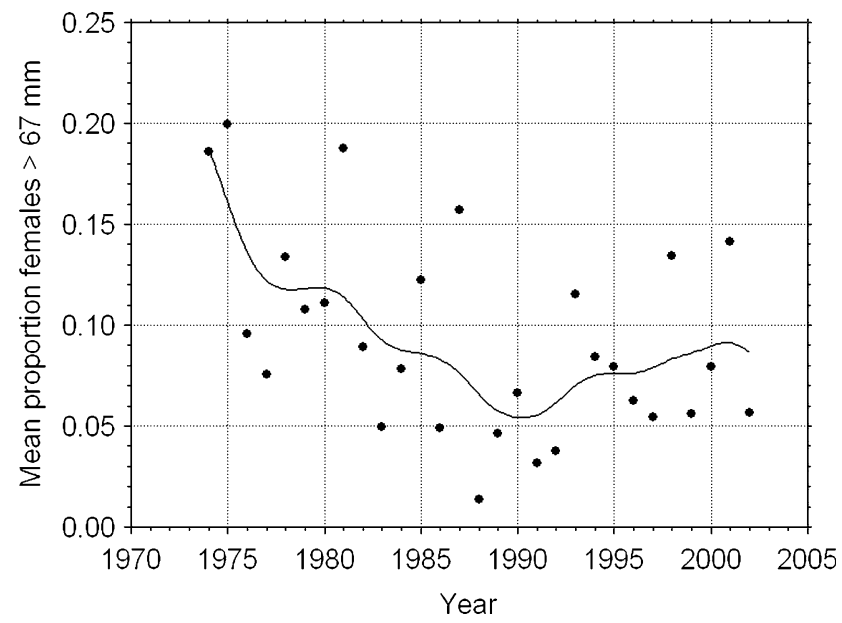

Fig. 6 Long-term interannual variation in proportion of very large shrimp ( $>67 \mathrm{~mm}$ as proportion of all shrimp $>54 \mathrm{~mm}$ ) in autumn (September); examples given from East and North Frisia

related to a simultaneous drop in proportion of large female size classes. Furthermore, the absolute density of large females in the stock shows no sign of congruence with those years of reduced female reproductive activity.

Since differences in size composition of the shrimp stock are not responsible for the changes in proportion of ovigerous females, we checked external factors which might influence the maturation process, i.e. mean monthly water temperature and freshwater run-off from the main rivers, climate factors such as NAO index, as well as biological factors such as fish predators (cod and whiting) and the commercial shrimp catches. These factors had been proven to affect abundance of shrimp (Siegel et al. 2005). Results of the non-parametric correlation analysis showed only very few significant correlations between variables and the proportion of ovigerous females. The proportion of ovigerous females is cross-correlated among the various areas; however, a clear relationship is not detectable between proportion of egg bearing females and environmental or biological parameters. Only for the Elbe estuary there is a weak indication that a high number of winter freezing days or low temperature is unfavorable for spawning $(T=-0.3271$ at $P<0.05)$. However, this correlation remained an isolated case and does not hold for the other regions where we observed the greatest changes in the occurrence of ovigerous females.

\section{Discussion and conclusions}

Sex ratio

Sex reversal from males to females, which was regarded important by Boddeke (1965), could not be observed in the 


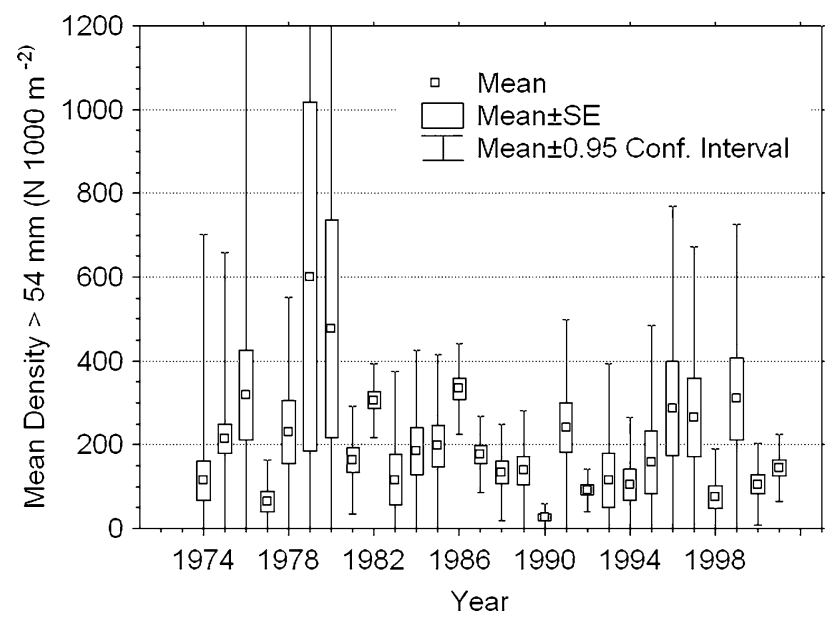

Fig. 7 Long-term interannual variation in numerical density of shrimp larger $54 \mathrm{~mm}$ in autumn (September), the graph shows the mean absolute density (and its standard error) of large females in all of the studied regions

rearing experiments of Tiews (1954) or Meixner (1970), Martens and Redant (1986) and Schatte and Saborowski (2005). Oh and Hartnoll (2004) inspecting gonads and external characteristics, respectively, found transitional stages only in a few percent of the specimens examined. Boddeke (1965), commenting on an analysis of a series of male gonad samples, did not mention the finding of gonads in transition, but rather stated in the discussion of that paper that "the great majority of female shrimps were of that sex at hatching". We thus join Martens and Redant (1986) in concluding that sex change may occur in this species occasionally, but with a frequency too low to have any perceivable effect on the sex ratios examined by us, or on other aspects of the life cycle and on management. It is assumed by us to be a negligible phenomenon.

The relationship of the sex ratio with size (Fig. 1) and the underlying frequency distributions (Fig. 2) clearly show a predominance of males in the smaller size groups after starting at roughly equal proportions. The upper end of the distribution is increasingly occupied by females. Such patterns are not uncommon (Wenner 1972), here they may be interpreted in different ways. If sex change can be excluded as an important factor, sexual differences in growth, mortality or migration habits may be invoked for explanation. Since faster growth for females towards larger final lengths was found in the tank experiments of Tiews (1954) and Meixner (1970), this gives a plausible explanation: males, because their final length is lower, accumulate in the lower half of the joint size distribution. Still, since the overall numbers of females are substantially higher through all the samples (by factor 1.2-2.0 in favor of females depending on the season) while the sex ratio is balanced at the beginning of the lifespan, mortality must also be seen as different between sexes.
It may be argued that the observed decline in medium sized female proportions can be attributed to differences in growth between males and females. If the growth rates were exactly the same between males and females, and mortality rates were also similar, the sex ratio should remain constant. If growth rates were exactly the same but one sex had higher mortality rate, then the sex ratio should change with shrimp size. To have consistent lows and highs, or concave and convex curves at certain length classes, as observed in our survey data, there must be a constant phase difference in the length frequency distributions between males and females due to a significantly higher growth rates in one sex compared to the other.

Female growth in brown shrimp is thought to be faster (Tiews 1970) but males may have a shorter average lifespan than females. The pattern of sex ratio plots is a result of mixed effects of the difference in growth rate between males and females, the mortality rates, and age composition. Growth rate differences cause a separation of the modal length for each sex at the same age classes, thus the sex ratio differs between size ranges. Difference in mortality rates will affect the height of the amplitude as well as the trend towards the larger end of the size spectrum. Larger differential mortality between sexes will result in a lower sex ratio if we define the fraction as $\mathrm{m} / \mathrm{f}$ and have an increased mortality rate for males. With the onset of the spring season females start to grow faster than males. Males spend longer times in the size range $30-45 \mathrm{~mm}$, while a large number of females grow fast across this size range, thus reducing the proportion of females for this size classes. Males accumulate in these size classes while growing more slowly over the summer. So the effect can still be seen during the September autumn survey. Until winter (January) males suffer a constant mortality which leads to a decrease in their proportion for size classes larger than $45 \mathrm{~mm}$.

Henderson and Holmes (1987) observed both slower growth and shorter lifespan for males, thus corroborating this interpretation. We are not able to decide what may cause such differences in mortality, but regard it as plausible that smaller individuals suffer higher predation mortality, as predicted by size spectrum theory (Beyer 1989). A physiological cause seems also possible, but we have no background information to conclude on that.

\section{Migration}

In theory it may be possible that we observe a length and sex dependent migration pattern. So in some instances we might have observed a situation when males might have migrated into the survey area whereas medium sized females still remain outside the coastal study area (see Boddeke 1976 on seasonal migration). However, the same concave and convex curves for females and males, 
respectively, occur in spring as well as in autumn. This shape of the curves would require a reverse migration pattern for males and females during spring and autumn seasons, an early immigration of males in spring and an early emigration of females of medium size classes in autumn whereas males remained in the area. However, according to Boddeke (1976) the timing of the seasonal emigration in autumn should occur much later in the year (November-December) than the survey (September) and the sequence of male and female migration would not fit with the shape of the sex ratio curve. Instead, our data from autumn and spring were taken before and after the typical time of this cyclic migration, such that little effect on the local sex ratios should be expected. Our winter data do in fact deviate from the others in that relatively less mediumsized males are present in the investigation area. Boddeke (1976) draws up a fairly complicated scheme for deviating migrations by sex and maturity stage, differing between cold and mild winters. It is thus difficult to verify whether our findings fit into that pattern given that our data are pooled over several years.

\section{Maturity cycle}

The curves for maturity-at-length (Fig. 3) for spring and winter strongly resemble each other in steepness, but this coincidence may be spurious. The distribution of the residuals-positive in the first half and rather negative in the second-indicates that the standard logistic function may not be the most appropriate one to model these data. Still, in the absence of theoretically demanding facts for the "true" function, only heuristic corrections would seem to be possible. At least, the $L_{50}$ value seems to be well estimated, considering the apparent symmetry of the relationships. However, since our "maturity" classification is based only on the presence of attached eggs, it was termed "apparent maturity", because a female may pass a molting phase without spawning though being mature ("resting"). While Henderson and Holmes (1987) used the same approach (their curve for ovigerous females does only reach 60\%), Oh and Hartnoll (2004) included gonadal state in their classification, and arrive at a maturity curve which is somewhat flatter than ours.

Two reasonably discrete spawning periods within the annual breeding season had been reported to occur in $C$. crangon (Lloyd and Yonge 1947 and Henderson and Holmes 1987 for the Bristol Channel, Meredith 1952 for the Liverpool Bay) with some latitudinal modifications (Kuipers and Dapper 1984). Indications for two broods (winter and summer) were also found by $\mathrm{Oh}$ and Hartnoll (2004) in the Irish Sea. For the Dutch coast Boddeke (1966) argues for two distinct peaks in the production of larvae, the first in January resulting from a spawning in October, and a second peak in March-April. Tiews (1970) claimed that shrimps in the German Wadden Sea show two spawning seasons, because eggs are larger in winter (November-March) than in summer (April-August). Settlement of postlarval shrimp in the German Wadden Sea was thought to occur in three batches, in May, during summer and an overwintering batch (del Norte-Campos and Temming 1998).

Defined batches cannot be seen in our data from the occurrence of ovigerous females. The continuous increase of ovigerous females from December onwards over late winter to a maximum between March and end of June and their rapid decline thereafter indicates the potential for continuous breeding. If there is a hatching of larvae in January from eggs carried by females through October and November, then their number should not be very high, because at this time of the reproductive season the proportion of ovigerous females is still developing and has not reached the maximum which generally occurs in late February to mid June.

While ovigerous females may be found year-round, there is a marked minimum between mid August and early December. The absence of egg-bearing female shrimp in September-October was explained by Boddeke (1965) through the absence of mature males in August-September. Bimodality in the summer values, as shown by Boddeke et al. (1986) for Dutch waters, is apparently not suggested by our data, although we studied North Frisia and East Frisia data separately and East Frisia is in close proximity to Dutch waters.

A distinct annual cycle in the occurrence of ovigerous females which is characterized by a gap in autumn and which is persistent through size groups and years is equally observed in other areas, e.g. Dutch waters (Havinga 1930) and the Irish Sea (Oh and Hartnoll 2004). Whereas in our data the duration of the gap is typically $2-3$ months around September-October, it covers virtually a half year (JulyDecember) in the findings of Oh and Hartnoll (2004). At the same time, the percentage of mature females reported by Oh and Hartnoll (2004) drops to zero or almost zero during July-October. Sexual maturity, once attained, is not reversible as opposed to the cyclic event of egg production and spawning. The observation could indicate that females die after the first spawning season. However, though not impossible, this is supported nowhere in the literature. If one assumes that the stages "immature" and "resting mature" were correctly classified by $\mathrm{Oh}$ and Hartnoll (2004), it remains that size- and/or stage-specific migration and depth preference may have biased the samples which were taken no deeper than at $6 \mathrm{~m}$. Assuming this, also the long absence of ovigerous females could be explained.

It appears that the basic seasonal life cycle of the brown shrimp population in the German Bight is well synchronized and fairly constant over time, even during periods 
with reduced maturity such as in the late 1980s, the cycle seems to continue relatively unchanged without major time displacement.

The cause of the reproductive pause is not clear at all. There are various options to explain the seasonal trend in ovigerous female occurrence. It could be hypothesized that suppression of egg production in these autumn months is the result of an internal regulation. An alternative mechanism for the observed patterns would be a minimum age for maturity that prevents the new year cohort from becoming mature as early as September or October. This mechanism could explain the patterns on the assumption that most of the shrimp in all size classes in autumn originate from the new cohort of the same year. In the field data both small and large shrimp do not carry eggs during the autumn period. According to Oh and Hartnoll (2004) the process is hormone-controlled, and reversible (Bomirski and Klek 1974). Boddeke (1965) noted that in the respective time interval also ripe males are absent in the population, but it remains an open question whether there is a synchronizing mechanism in force. The unimodal appearance of the quantity of the egg-bearing fraction through the year (Fig. 4) does not support the idea of two spawning seasons in German waters which is carried over since Ehrenbaum (1890). It is based on the finding that there is a phase of spawning of larger "winter eggs", which is followed from about March onwards (Boddeke 1982) by the production of smaller "summer eggs". However, regarding the whole population, there is no gap in the fraction of egg-bearing females which would allow distinguishing two separate seasons. There is indeed a marked decrease in the (modeled) spawning activity in February (Temming and Damm 2002) which is caused by the water temperature minimum in that month (and which coincides with the limit between winter and summer eggs). Since all vital processes of the species are temperature-dependent, the hatching rate slows down accordingly, and no reduction in egg-carrying is observed. One may thus conclude that the spawning season is continuous, but varying in intensity according to the environmental temperature.

\section{Interannual variability}

Despite the fairly constant seasonal cycle in brown shrimp life history, the results from the long-term data set demonstrate a high variability in the fraction of ovigerous females over the years. These data show a trough of conspicuously low values within the data series for all three studied sub-areas, however, with differences in timing and duration. Regarding the conspicuous decrease in eggbearing in the second half of the 1980s as demonstrated in Fig. 5, we lack any convincing explanation that the phenomenon was based on environmental factors.
One might assume that the observed differences in the interannual trend for reproductive success are an artifact of delayed or advanced life cycle events coupled with a rigidly timed survey. However, the data up to 1992, when the recovery phase had already started, were obtained from weekly samples of the commercial fishing vessels. The effect of very low reproductive success is obvious from Fig. 4d as a multi-year event, for East Frisia at least for 1982-1991. This figure shows the weekly progress in the occurrence of ovigerous females and clearly demonstrates that neither advanced life cycle events nor delay in spawning occurred in these years. During those years the proportion of spawning females never exceeded $40 \%$ for the entire reproductive season or even dropped below $10 \%$ in 4 out of 10 years. The long-term decline became first visible in East Frisia since about 1978, followed much later by $C$. crangon in North Frisia waters not before 1984. After 1991, a simultaneous and abrupt rise and improvement occurred in all subareas. It seems that this "drop" in spawning success showed a succession from south-west to north-east over several years along the German coast. Correlation analyses with common parameters, such as water temperature, river runoff, NAO climate index, fish predator density or fishing pressure showed no obvious simple plausible proximate cause. It was not related to average size in the female population (larger females produce more eggs), though there was a continuous decline in average female size through the 1950 s to the $1990 \mathrm{~s}$, but this trend did not show a respective trough in late 1980s.

Hidden effects are currently speculative; however, one potential source could be seen in the health status of the shrimp population, including parasite load and the presence of microbial pathogens (Stentiford and Feist 2005). While some bacilliform virus are found in C. crangon, particularly in the hepatopancreas or the midgut (Stentiford et al. 2004), other pathological infections appear with gonad tissues. For several years in the early to late 1980s the fraction of shrimp in the North Sea showing "black spot disease" in the shell has been growing. Infection rates of $3-$ $31 \%$ were reported for the German coast in 1979-1980, and $16-22 \%$ in 1982, with highest values in the western part of the German Bight (Watermann and Dethlefsen 1983). Knust (1990) reported on infection rates up to $58 \%$ between 1986 and 1988, with highest values for larger shrimp size classes, consequently affecting the mature female population most. In some locations in southern England infection rates of $C$. crangon were reported to be as high as 87\% in 1988 and 1989 (Dyrynda 1998). Possible causes were discussed as abrasions or pollutant-induced dissolutions of the shell and subsequent infections by bacteria and fungi (Watermann and Dethlefsen 1983). Histological observations showed that the black spots were melanized nodules and that these nodules often contained 
more than one type of bacteria. The melanized nodules were almost always accompanied by tumor-like cells, which seemed to be derived from a gonad tissue. Even if the disease does not directly cause mortality in the shrimp, the development of such a tumor-like cell mass in the gonad can affect reproduction of the organism.

It should be noted that the large drop in reproductive output did show some effects in the stock abundance indices for larger than $54 \mathrm{~mm}$ shrimp off East Frisia between 1986 and 1993. However, this effect was less obvious in the other areas Elbe estuary and North Frisia. One may extract here the comforting message that the size of the effective spawning stock is not crucial for the prosperity of the population, as also seen in the instantaneous recovery after population downward spikes caused by massive predation events on top of environmental factors (Siegel et al. 2005). Such events occurred in the years 1977, 1983, 1990, 1998 and 2007, when cod and/or whiting 0-groups were extremely abundant (Tiews 1961; Berghahn 1996; ICES 1998; Siegel et al. 2005). It is also in line with the speculations of Temming and Damm (2002), that the German Bight brown shrimp stock is replenished from more westerly (Dutch) waters, which fits very well into their modeling exercise.

Havinga (1930) and Tiews (1954) defended the fishing of undersized shrimps as a minor problem, because they believed that small shrimps are predominantly males which will never reach the size of consumption shrimps (>55 mm). Boddeke (1965) rejected this fishing practice, because he thought that male shrimp change sex and continue to grow as females and attain the size of consumption shrimps. In this case a fishery with a high by-catch rate of undersized shrimp would negatively impact on the large size groups which represent the female spawning stock. Conclusions from our data are similar to Boddeke (1965), but for different reasons. We cannot confirm that small shrimp are predominantly males, but our data on sex ratio and length frequencies show a more complex situation with changing ratios around $50 \%$ on average. However, we can also not confirm the sex change in males (see above), but the synoptic occurrence of males and females during the entire growth period of the small size groups. Having small males and female size classes present would support the concern that at least the female portion of the population could suffer from a fishery of undersized shrimps and negatively impact on the large individuals of the breeding stock.

Acknowledgments This work would not have been possible without the many people spending weeks at sea year after year, collecting and measuring samples. We especially thank our colleagues KarlHeinz Becker, Gitta Hemken, Thomas Kehlert and Susanne Schöling for their great assistance during the past years of the survey timeseries. We are also grateful to Andy Lawler and one anonymous referee for their constructive comments and assistance to improve the manuscript.

\section{References}

Berghahn R (1996) Episodic mass invasions of juvenile Gadoids into the Wadden Sea and their consequences for the population dynamics of Brown Shrimp (Crangon crangon). Marine Ecology/ Pubblicazioni Della Stazione Zoologica Di Napolii 17:251-260

Beyer JE (1989) Recruitment stability and survival—simple sizespecific theory with examples from the early life dynamics of marine fish. Dana 7:45-147

Boddeke R (1965) Methods to improve the yield of the Dutch shrimp fishery. Rapp Proc Verb 156:8-10

Boddeke R (1966) Sexual cycle and growth of brown shrimp (Crangon crangon). ICES C.M. Shellfish Cttee 1966 (M6): 1-2

Boddeke R (1976) The seasonal migration of the brown shrimp Crangon crangon. Neth J Sea Res 10:103-130

Boddeke R (1982) The occurrence of winter and summer eggs in the brown shrimp (Crangon crangon) and the pattern of recruitment. Neth J Sea Res 16:151-162

Boddeke R, Driessen G, Doesburg W, Ramaekers G (1986) Food availability and predator presence in a coastal nursery area of the brown shrimp (Crangon crangon). Ophelia 26:77-90

Bomirski A, Klek E (1974) Action of eyestalks on ovary in Rhithropanopeus harrisii and Crangon crangon (CrustaceaDecapoda). Mar Biol 24:329-337

Del Norte-Campos AGC, Temming A (1998) Population dynamics of the brown shrimp Crangon crangon L., in shallow areas of vthe German Wadden Sea. Fish Manage Ecol 5:303-322

Dyrynda EA (1998) Shell diseases in the common shrimp Crangon crangon: variations within an enclosed estuarine system. Mar Biol 132:445-452

Ehrenbaum E (1890) Zur Naturgeschichte von Crangon vulgaris Fabr. Studien über Bau, Entwicklung. Lebensweise und Fangverhältnisse des Nordsee-Granat. Mitteilungen der Sektion für Küsten- und Hochseefischerei. Moeser Verlag, Berlin, pp 1-112

Havinga B (1930) Der Granat (Crangon vulgaris Fabr.) in den holländischen Gewässern. J Cons Int Exp Mer 5:57-87

Henderson PA, Holmes RHA (1987) On the population biology of the common shrimp Crangon crangon (L.) (Crustacea: Caridea) in the Severn Estuary and Bristol Channel. J Mar Biol Assoc UK 67:825-847

Lloyd A, Yonge (1947) The biology of Crangon crangon L. in the Bristol Channel and Severn Estuary. J Mar Biol Assoc UK 26:626-661

ICES (1998) Report of the Working Group on Crangon fisheries and life history. CM 1998/G:8. pp 99

Knust R (1990) The black-spot disease in Crangon crangon (L.) of the German Bight. ICES CM 1990/E:32 pp 1-9

Kuipers BR, Dapper R (1984) Nursery function of Wadden Sea tidal flats for the brown shrimp Crangon crangon. Mar Ecol Prog Ser 17:171-181

Martens E, Redant F (1986) Protandric hermaphroditism in the brown shrimp, Crangon crangon (L.), and its effects on recruitment and reproductive potential. ICES CM 37:1-20 $1986 \mathrm{~K}$

Meixner R (1970) Größenzunahme bei der Häutung von Crangon crangon aus der Nordsee und Ostsee. Ber Deutschen Wissenschaftl Kommission Meeresf 21:393-398

Meredith SS (1952) A study of Crangon vulgaris in the Liverpool Bay area. Proc Trans Loverp Biol Soc 58:75-109

Neudecker T, Damm U (1992) Seasonality of egg-bearing shrimp (Crangon crangon L.) in coastal waters of the German Bight. ICES CM 28:1-9 $1992 \mathrm{~K}$ 
Neudecker T, Fischer J, Damm U (1998) Influence of tidal currents on fishing performance in the Wadden Sea: ICES CM 6:1-12 1998/ BB

Oh CW, Hartnoll RG, Nash RDM (2001) Feeding ecology of the common shrimp Crangon crangon in Port Erin Bay, Isle of Man, Irish Sea. Mar Ecol Prog Ser 214:211-223

Oh CW, Hartnoll RG (2004) Reproductive biology of the common shrimp Crangon crangon (Decapoda: Crangonidae) in the central Irish Sea. Mar Biol 144:303-316

Plagmann J (1939) Ernährungsbiologie der Garnele (Crangon vulgaris Fabr.). Helgol Wiss Meeresunters 2:113-162

Pihl L, Rosenberg R (1984) Food selection and consumption of the shrimp Crangon crangon in some shallow marine areas in western Sweden. Mar Ecol Prog Ser 15:159-168

Reise K (1977) Predator exclusion experiments in an intertidal mudflat. Helgol Mar Res 30:263-271

Reise K (1979) Moderate predation on meiofauna by the macrobenthos of thr Wadden Sea. Helgol Mar Res 32:453-465

Schatte J, Saborowski R (2005) Change of external sexual characteristics during consecutive moults in Crangon crangon $\mathrm{L}$. Helgol Mar Res 60:70-73

Siegel V, Gröger J, Neudecker T, Damm U, Jansen S (2005) Longterm variation in the abundance of the brown shrimp Crangon crangon (L.) population of the German Bight and possible causes for its interannual variability. Fish Oceanogr 14:1-16

Stentiford GD, Feist SW (2005) A histopathological survey of shore crab (Carcinus maenas) and brown shrimp (Crangon crangon) from six estuaries in the United Kingdom. J Invert Pathol 88:136-146

Stentiford GD, Bateman K, Feist SW (2004) Pathology and ultrastructure of an intranuclear bacilliform virus (IBV) infecting brown shrimp Crangon crangon (Decapoda: Crangonidae). Dis Aqauat Org 58:89-97

Temming A, Damm U (2002) Life cycle of Crangon crangon in the North Sea: a simulation of the timing of recruitment as a function of the seasonal temperature signal. Fish Oceanogr 11:45-58

Tiews K (1954) Die biologischen Grundlagen der Büsumer Garnelenfischerei. Ber Dt Wissenschaftl Komm Meeresf 13:235-269

Tiews K (1961) The role of whiting as an undesirable guest in German coastal waters. ICES Near Northern Seas Cttee (1961) $28: 1-8$

Tiews K (1970) Synopsis of biological data on the common shrimp Crangon crangon (Linnaeus, 1758). FAO Fish Rep 57:11671224

Tiews K (1978) The predator-prey relationship between fish populations and the stock of brown shrimp (Crangon crangon L.) in German coastal waters. Rapp P-v Réun Cons Int Explor Mer 172:250-259

Tiews K (1990) 35-Jahres-Trend (1954-1988) der Häufigkeit von 25 Fisch- und Krebstierbeständen an der deutschen Nordseeküste. Arch FischWiss 40:39-48

van Beek FA, Rijnsdorp AD, De Clerk R (1989) Monitoring juvenile stocks of flatfish in the Wadden Sea and the coastal areas of the southeastern North Sea. Monitoring the Wadden Sea. Proceedings of the 6th International Wadden Sea Symposium. Helgoländer Meeresuntersuchungen 43: 461-477

Wenner AM (1972) Sex ratio as a function of size in marine Crustacea. Am Nat 106:321-350

Watermann B, Dethlefsen V (1983) Black spot disease of shrimpsan environmental problem, a disease or wounds. Inf Fischwirtsch 30:24-29 